\title{
LENGTH-WEIGHT RELATIONS OF SELECTED SPECIES OF THE FAMILY GERREIDAE (ACTINOPTERYGII: PERCIFORMES) FROM THE MEXICAN COAST
}

\author{
José DE LA CRUZ AGÜERO*, Francisco J. GARCÍA RODRÍGUEZ, \\ Víctor M. COTA GÓMEZ, Jorge G. CHOLLET VILLALPANDO, \\ and Francisco J. VERGARA SOLANA
}

\begin{abstract}
Centro Interdisciplinario de Ciencias Marinas, Colección Ictiológica, Apartado Postal 592, La Paz, Baja California Sur, México 23000. http://coleccion.cicimar.ipn.mx
\end{abstract}
De La Cruz Agüero J., García Rodríguez F.J., Cota Gómez V.M., Chollet Villalpando J.G., Vergara Solana F.J. 2011. Length-weight relations of selected species of the family Gerreidae (Actinopterygii: Perciformes) from the Mexican coast. Acta Ichthyol. Piscat. 41 (1): 67-69.

\begin{abstract}
In this study, parameters of the length-weight relation (LWR) were estimated for fifteen species of Gerreidae (mojarras) caught from the Pacific- and Atlantic coast of Mexico, including the Gulf of California. The Pacific species were: Diapterus aureolus, Diapterus brevirostris, Eucinostomus currani, Eucinostomus dowii, Eucinostomus entomelas, Eucinostomus gracilis, Eugerres axillaris, Eugerres lineatus, and Gerres cinereus. The Atlantic species were: Diapterus auratus, Eucinostomus argenteus, Eucinostomus gula, Eucinostomus jonesi, Eucinostomus melanopterus, and Eugerres plumieri. The values of the exponent $b$ of the length-weight relation ranged from 2.58 to 3.79 . To the best of our knowledge, these are the first parameter estimates for nine species for the Mexican coast and for four on a worldwide scale.
\end{abstract}

Keywords: fish, length-weight relation, Gerreidae, Mexico

Fish of the family Gerreidae, commonly known as mojarras or silver biddies, are one of the most representative groups of fishes in the tropics and subtropics worldwide. The mojarras species live mainly in estuaries, lagoons, and sheltered bays, often showing a sympatric distribution (Matheson and McEachran 1984, De La CruzAgüero et al. 1994). However, it is known that most Gerreidae make frequent incursions into inland waters (Castro-Aguirre et al. 1999) and in some cases, such as the Mexican mojarra, Eugerres mexicanus, they are exclusive inhabitants of fresh waters (Deckert and Greenfield 1987). These species form large schools that are exploited by commercial fisheries especially in Southeast Asia, where catches constituted mainly by the genus Gerres, exceed $10000 \mathrm{t}$ per year (Anonymous 1995). In Mexico, although they are not exploited for human consumption on a large scale, they are valuable artisanal fishery resources (Yáñez Arancibia 1980).

In spite of the manifest abundance and ecological importance of Gerreidae species, there are few studies that address biological aspects relevant for fisheries management. In this context, the analyses that involve length-weight relations (LWR) have increased, because information on LWR is required to determine the conver- sion of growth-in-length equations to growth-in-weight population parameters (Harrison 2001). This information is necessary for determining stock structure as well as for estimates of fish condition and other applications in fisheries resource planning and management (Mendes et al. 2004, Ismen et al. 2009).

Here we report the parameters of the LWR of fifteen species of Gerreidae caught in the Pacific and Atlantic coast of Mexico. To the best of our knowledge, there is no information on the LWR for four of these species (those without a code in Table 1), while for the others the studies are from restricted sites (Froese and Pauly 2010). Our aim is to make these data available for the purpose of estimating length and age structures, standing-crop biomass (number or biomass per unit area), and growth rates of gerreid species and so enhance understanding of their ecology.

Between 2006 and 2009, samples were collected from Mexico's Pacific coast (Gulf of California, Mazatlán, Nayarit, and Acapulco) and its Atlantic coast (Gulf of Mexico, Veracruz, and Yucatán), using different fishing gear, and were preserved in $10 \%$ formalin for transportation to the laboratory where they were identified. All specimens were quantified by the number of individuals and were deposited and catalogued in the fish collection

\footnotetext{
* Correspondence: Dr. José De La Cruz Agüero, Centro Interdisciplinario de Ciencias Marinas, Colección Ictiológica, Apartado Postal 592, La Paz, Baja California Sur, México 23000, phone: (+612) 122-5366, fax: (+612) 122-5322, e-mail: jcruz@ipn.mx.
} 
(CI) of the Centro Interdisciplinario de Ciencias Marinas in La Paz, Baja California Sur, Mexico. In the CI laboratory, total length (TL) to the nearest $1 \mathrm{~mm}$ and gross weight to the nearest $0.01 \mathrm{~g}$, of all fish were measured. For the analysis of LWR, we excluded very small specimens $(<1.0 \mathrm{~cm} \mathrm{TL})$ in order to avoid unreasonable values for LWR parameters. The allometric equation $W=a L^{b}$ (see below) was fitted to the length-weight data. The $a$ and $b$ parameters of the model were estimated by the least-squares method applied to the log-transformed data according to the formula:

$$
\log W=\log a+b \log L
$$

where $W$ is the total weight [g], $L$ is the total length [cm], $a$ is the intercept and $b$ is the slope, of the length-weight relation. The model parameters were estimated using the XLSTAT Pro version 2010 computer program (a complement program for MS Excel 2007).

In this study, 5052 specimens belonging to fifteen species of Gerreidae were analyzed. Sample size ranged from 17 for the striped mojarra (Eugerres plumieri) to 1956 for the dark-spot mojarra (Eucinostomus entomelas). All sample sizes $(n)$, minimum and maximum length and weight, parameters of LWR ( $a$ and $b$ ), 95\% confidence limits of $b$, and the coefficient of determination $\left(r^{2}\right)$ by species, are presented in Table 1.
According to Koutrakis and Tsikliras (2003), the parameter $b$ varies between 2 and 4 , but in the present study it ranged from a minimum of 2.58 for the Black axillary mojarra (Eugerres axillaris) to a maximum of 3.79 for the Irish mojarra (Diapterus auratus). These values can be considered within the expected range for fish (Froese 1998). The average value of $b$ was 3.06 ; nearly $90 \%$ of $b$-values were between 2.5 and 3.2 , with coefficients of determination $\left(r^{2}\right) \geq 0.94$ in thirteen species. In consequence, current parameters can be used at least to derive weight estimates from a given value of length or vice versa, although limited to the size ranges used to estimate the parameters.

Several artefacts and biological factors are known to affect fish LWR. The differences in the values of $b$ have been attributed in other studies to several factors: sex, gonad maturity, growth phase, health, food availability, stomach fullness, season, water temperature, salinity, and even preservation techniques (Yı̆̆ın and Ismen 2009, Robinson et al. 2010). Although we did not take any of these into account, in the present work these differences can also be attributed in part to the number of specimen examined and to the observed length ranges of the species caught.

LWR estimates for eleven of the fifteen species studied here are also available in FishBase (Froese and Pauly 2010) but to the best of our knowledge no LWR information currently exists for the remainder. For the Mexican coast

Table 1

Length-weight relations for selected species of Gerreidae (mojarras) from the Pacific and Atlantic coast of Mexico

\begin{tabular}{|c|c|c|c|c|c|c|c|c|c|c|c|c|c|}
\hline & \multirow{2}{*}{ Species } & \multirow{2}{*}{ tatus } & & \multicolumn{4}{|c|}{ Parameters of the LWR } & \multicolumn{3}{|c|}{ Length } & \multicolumn{3}{|c|}{ Weight } \\
\hline & & & & $a$ & $b$ & $r^{2}$ & $95 \% \mathrm{CI}$ of $b$ & Min. & Max. & Mean & Min. & Max. & Mean \\
\hline \multirow{9}{*}{ 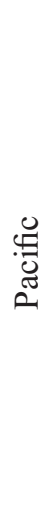 } & Diapterus aureolus & & 45 & 0.019 & 2. & 0.89 & 02 & 8.5 & .5 & 10.2 & 9.3 & 20.4 & 14.6 \\
\hline & D. brevirostris & & 865 & 0.017 & 3.21 & 0.98 & $3.18-3.24$ & 1.7 & 17.0 & 4.4 & 0.04 & 164.3 & 5.9 \\
\hline & Eucinostomus dowii & FB & 284 & 0.016 & 3.12 & 0.98 & $3.07-3.16$ & 1.0 & 17.6 & 4.3 & 0.06 & 162.2 & 13.2 \\
\hline & E. currani & FB & 1000 & 0.013 & 3.18 & 0.99 & $3.17-3.19$ & 2.7 & 9.0 & 3.3 & 0.34 & 16 & 0.75 \\
\hline & E. entomelas & FB & 1956 & 0.019 & 3.03 & 0.98 & $3.01-3.04$ & 1.6 & 10.6 & 4.3 & 0.12 & 23.3 & 2.7 \\
\hline & E. gracilis & FB & 548 & 0.014 & 3.19 & 0.96 & $3.16-3.21$ & 1.8 & 5.6 & 3.4 & 0.08 & 3.2 & 0.78 \\
\hline & Eugerres axillaris & & 37 & 0.053 & 2.58 & 0.99 & $2.56-2.60$ & 3.7 & 18.1 & 11.3 & 1.6 & 94.7 & 36.4 \\
\hline & Eugerres lineatus & & 41 & 0.061 & 2.71 & 0.97 & $2.61-2.82$ & 4.9 & 20.5 & 15.1 & 2.6 & 255 & 122.9 \\
\hline & Gerres cinereus & FB & 71 & 0.029 & 2.82 & 0.99 & $2.74-2.91$ & 1.3 & 20.8 & 7.1 & 0.05 & 241.6 & 37.5 \\
\hline \multirow{6}{*}{ 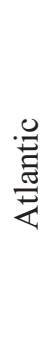 } & Diapterus auratus & FB-M & 25 & 0.004 & 3.79 & 0.99 & $3.78-3.80$ & 7.5 & 17.3 & 11.2 & 9.0 & 192.9 & 49.3 \\
\hline & Eucinostomus gula & FB & 42 & 0.035 & 2.83 & 0.88 & $2.69-2.97$ & 2.9 & 11.4 & 7.0 & 0.73 & 31.4 & 10.0 \\
\hline & E. argenteus & FB-M & 51 & 0.008 & 3.38 & 0.94 & $3.33-3.44$ & 2.0 & 11.5 & 6.6 & 0.02 & 30.7 & 6.3 \\
\hline & E. jonesi & FB-M & 29 & 0.092 & 2.65 & 1.00 & $2.65-2.65$ & 1.6 & 14.9 & 5.6 & 0.33 & 118.6 & 17.8 \\
\hline & E. melanopterus & FB-M & 41 & 0.006 & 3.62 & 0.95 & $3.52-3.66$ & 6.7 & 8.6 & 10.3 & 5.7 & 28.9 & 5.0 \\
\hline & Eugerres plumieri & FB-M & 17 & 0.048 & 2.93 & 1.00 & $2.93-2.93$ & 6.9 & 16.3 & 12.5 & 14.1 & 172.9 & 47.6 \\
\hline
\end{tabular}

Species listed according to nomenclature in Froese and Pauly (2010); $n$, sample size; Min. and Max, minimum and maximum length [cm] and weight $[\mathrm{g}] ; a$ and $b$, parameters of the relations; $95 \% \mathrm{CI}$ of $b$, confidence limits of $b ; r^{2}$, coefficient of determination; FB,species cited in FishBase; - M, species cited but not for the Mexican coast. 
in particular, there is no data in FishBase for nine of the species here included. Furthermore, for those species included, the confidence intervals for $a$ and $b$ are not available, thus precluding a direct comparison. Moreover, for five of those in the Pacific Ocean, the values come from highly restricted sites such as a small mangrove swamp in La Paz bay, Gulf of California, Mexico (González-Acosta et al. 2004).

\section{ACKNOWLEDGEMENTS}

The authors wish to express their gratitude for the financial support of the Ichthyology Collection (CI) at CICIMAR-IPN (http://coleccion.cicimar.ipn.mx) provided by SIP-IPN, CONABIO and CONACyT. JDA and FJGR are also grateful for the grants from SNICONACyT, COFAA-IPN and EDI-IPN, while JGCV and FJVS acknowledge the PIFI-IPN and CONACyT scholarship. The authors would like to thank V.A. Tapia-Rendón and J.A. Payán-Alcacio for their invaluable assistance in the fish samplings. Finally, we also thank Roger Dunne for his English assistance in preparing the manuscript.

\section{REFERENCES}

Anonymous 1995. FAO yearbook: Fishery statistics - catches and landings 1993. FAO, Rome.

Castro-Aguirre J.L., Espinosa-Pérez P.H., Schmitter-Soto S.J.J. 1999. Ictiofauna estuarino-lagunar y vicaria de México. Editorial Limusa, Mexico, DF.

Deckert G.D., Greenfield D.W. 1987. A review of the western Atlantic species of the genera Diapterus and Eugerres (Pisces: Gerreidae). Copeia 1987 (1): 182-194. DOI: $10.2307 / 1446051$.

De La Cruz-Agüero J., Galván-Magaña F., Abitia-Cárdenas L., Rodríguez-Romero J., Gutiérrez-Sánchez F. 1994. Lista sistemática de los peces marinos de Bahía Magdalena, Baja California Sur (México). Ciencias Marinas 20 (1): 17-31.

Froese R. 1998. Length-weight relationships for 18 less-studied fish species. Journal of Applied Ichthyology 14 (1-2): 117-118. DOI: 10.1111/j.1439-0426.1998.tb00626.x.

Froese R., Pauly D. (eds.) 2010. FishBase. [version 03/2010] http://www.fishbase.org.

González Acosta A.F., De La Cruz Agüero G., De La Cruz Agüero J. 2004. Length-weight relationships of fish species caught in a mangrove swamp in the Gulf of California
(Mexico). Journal of Applied Ichthyology 20 (2): 154-155. DOI: 10.1046/j.1439-0426.2003.00518.x.

Harrison T.D. 2001. Length-weight relationships of fishes from South African estuaries. Journal of Applied Ichthyology 17 (1): 46-48. DOI: 10.1046/j.1439-0426.2001.00277.x.

Ismen A., Cigdem Yigin C., Altinagac U., Ayaz A. 2009. Length-weight relationships for ten shark species from Saros Bay (North Aegean Sea). Journal of Applied Ichthyology 25 (Suppl. 1): 109-112. DOI: 10.1111/j.1439-0426.2009.01263.x.

Koutrakis E.T., Tsikliras A.C. 2003. Length-weight relationships of fishes from three northern Aegean estuarine systems (Greece). Journal of Applied Ichthyology 19 (4): 258-260. DOI: 10.1046/j.1439-0426.2003.00456.x.

Matheson R.E.jr., McEachran J.D. 1984. Taxonomic studies of the Eucinostomus argenteus complex (Pisces: Gerreidae): Preliminary studies of external morphology. Copeia 1984 (4): 893-902. DOI: 10.2307/1445334.

Mendes B., Fonseca P., Campos A. 2004. Weight-length relationships for 46 fish species of the Portuguese west coast. Journal of Applied Ichthyology 20 (5): 355-361. DOI: 10.1111/j.1439-0426.2004.00559.x.

Robinson L.A., Greenstreet S.P.R., Reiss H., Callaway R., Craeymeersch J., de Boois I., Degraer S., Ehrich S., Fraser H.M., Goffin A., Kröncke I., Lindal Jorgenson L., Robertson M.R., Lancaster J. 2010. Length-weight relationships of 216 North Sea benthic invertebrates and fish. Journal of the Marine Biological Association of the United Kingdom 90 (1): 95-104. DOI: 10.1017/S0025315409991408.

Yáñez Arancibia A. 1980. Taxonomía, ecología y estructura de las comunidades de peces en lagunas costeras con bocas efímeras del Pacífico de México. Centro de Ciencias del Mar y Limnología, Universidad Nacional Autónoma de México, Publicación Especial 2: 1-306.

Yığın C.C., Ismen A. 2009. Length-weight relationships for seven rays from Saros Bay (North Aegean Sea). Journal of Applied Ichthyology 25 (Suppl. 1): 106-108. DOI: 10.1111/j.1439-0426.2008.01161.x.

Received: 9 May 2010

Accepted: 26 August 2010

Published electronically: 25 March 2011 